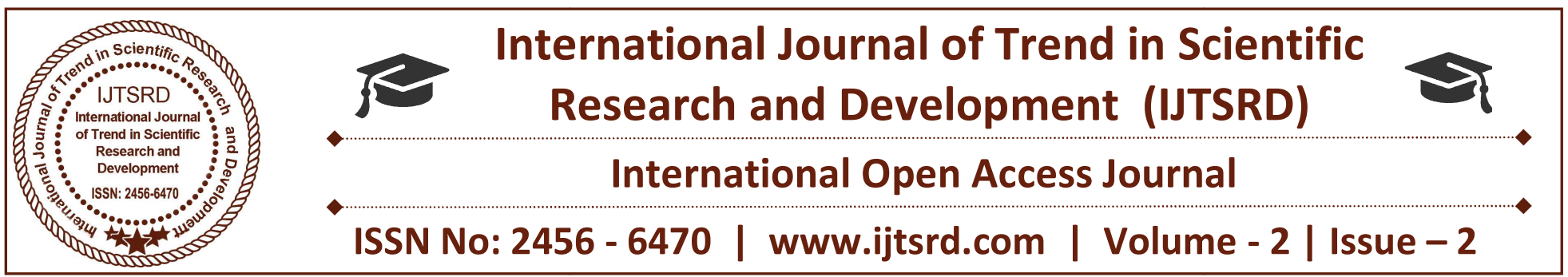

\title{
Perception of Employees towards Quality Work Life in Garment Industry
}

K. Prabha Kumari, B.E., MBA., M.Phil., (Ph.D)

Assistant Professor, Department of Apparel

Manufacturing and Merchandising, NIFT-TEA College of Knitwear Fashion, Tirupur, Tamil Nadu, India

\section{S. Ganesh}

Student, Department of Apparel Manufacturing and Merchandising, NIFT-TEA College of Knitwear Fashion, Tirupur, Tamil Nadu, India

\section{ABSTRACT}

In the garment sector to retain the skilled employee a Good quality of work life is necessary for an organization to attract and to sustain skilled and talented employees. In order to survive in the competitive market because of liberalization, privatization and globalization and to minimize the attrition rate of employees the QWL initiatives are very important in the garment industry QWL involves wide variety of components that are influenced on the performance satisfied level of employees .This study focuses and analyses the literature findings which involve QWL, Therefore, the researcher highly recommend those multinational companies to plan an excellent quality of work life (QWL) programs by focusing on particular service element $s$ that will further enhance the overall quality of life (QOL) of employees.

In this paper, the researchers found that quality of work life (QWL) programs influence the employees in organization and the researcher given suggestion by using the tools like Chi-square to improve the Welfare of the Employees.

Keywords: Quality of Work life, Perception, retaining, garment and chi square

\section{INTRODUCTION}

The Quality of life usually designates the desired outcome of social policies and programmers to focus the employees to the factors, in this area of disciplines, welfare and environment in many countries on the different levels of employees in the garment sector.

In the Organization Quality of Work-Life (QWL) Project at the centre was initiated by the president of the cancer centre based on anecdotal evidence of low morale and high burnout among employees. A steering committee composed of employee representatives from a variety of departments was administered to employees to gather baseline data on issues that they believed to be important to employees' quality of work-life. A QWL survey was developed towards the sustain employees to improve the level in the organization. 


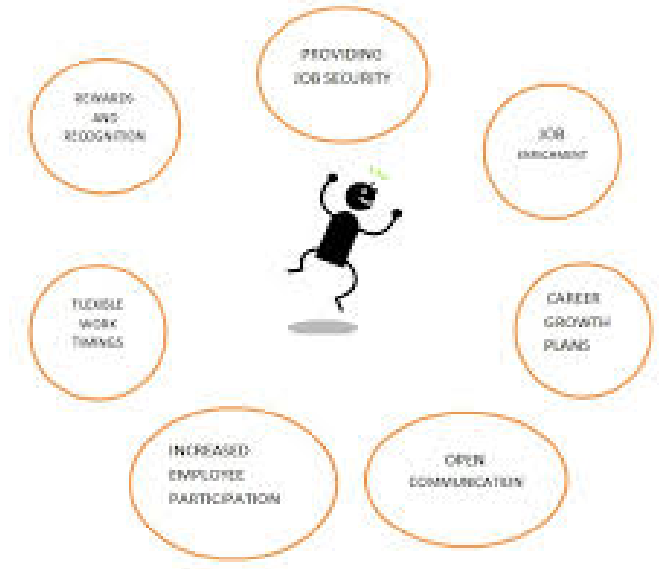

Fig - no :1

The QWL of people and places depends upon many things ,good paying jobs .some of these challenges are related to problems in the main stream economy while others, are unique to the institutional framework of rural area. Each of these aspects of development is complex since each community has its own growth related challenges and unique circumstances that affect its response to the pressures of growth.

\section{DEFINITIONS:}

The quality of life is a set of affective beliefs directed towards the totality of ones's life or towards specific domains of life.

\section{Andrews and withey :}

The quality of life is a "psychological state or feeling and therefore a pleasure the, happiness, well being or satisfaction"

"Brock" divides the good for persons or of a good life distinguishes 3 approaches

\section{$>$ Hedonist \\ $>$ Preference satisfaction \\ $>$ Ideal}

Much of the philosophical work on these theories has been in the services of developing on account of utility, broadly constructed for employment in consequentiality of QWL. The particular kinds of conscious experience are variously characterized as pleasure, happiness or the satisfaction or enjoyment that typically accompanies the successful pursuit of one's desires.

\section{NEED OF THE STUDY:}

The quality of life is one of the invisible components for every individual life to improve the quality life of employee better in the garment industry .The commitment and the desire of individual showed the meaning of life. This meaning will show the worth of life to make the employee into the worth the quality work life to the garment sector.

In order to understand the individual life the quality of life to individual has a lot of other components will be discussed in this research paper.

According to the research the quality work life is very important to the conducted a study according to this specified area according to specialization. So the researcher selects this topic to improve the quality of life is very much important for every individual in the organization

\section{OBJECTIVES THE STUDY:}

To study the employees perception about quality of life and to determine their overall quality of life.

To know the socio economic feature of employee in garment industry

To find out various factors affecting the quality of life among the employees.

To analyze the work life satisfaction towards welfare facilities and working environment in apparel industry the quality life.

$>$ To offer the suggestions to improve the quality life of employee.

\section{RESEARCH METHODOLOGY}

The present study is to analyze the Quality of Work Life (QWL) of at different stages of the manufacturing process, workforce is significant. Hence, the study workers are the focus of the present study on the Quality of Work Life for that garment industries in tirupur were selected to conduct the study.

\section{Aim of the Study}

The main aim of the present study is to determine the quality of work life of employees where they are facing low level of wages, poor working conditions, long working hours, and unfavorable terms of employment discrimination at work and also observed their satisfaction at work. To understand the practical relevance of designing and implementing the strategies and interventions to improve QWL among the workers working in the garment sector. 


\section{Sample Selection}

Simple random sampling is a selected where it comes under the probability sampling method. Simple random sampling is used to find the employees randomly to analyze to the research interest, and when investigators wish to oversample a particularly small group of interest.

\section{Methods of Data Collection}

Keeping in view the objectives of the study, the following methods for data collection have been followed by the researcher to conduct the present study. Both primary and secondary methods were followed for data collection.

\section{Primary Data}

The study focuses on the perceptions and attitudes of employees in relation tithe various quality of work life parameters like health and safety, employee welfare, working conditions, job security; wages; career growth and development; grievance handling system; social integration; and social relevance of work life..

\section{REVIEWS OF LITERATURE:}

This study presents the review of literature available on the subject of Quality of Work Life (QWL). The literature helps in developing a proper perspective of the subject and understanding the dimensions covered by the studies.

\section{G. Susila, R. Mathivanan, and K. Maruthadurai} (2013) they explained a study on the quality of work life in selected Cement Industries of Tancem, Birla and Ramco, in Ariyalur District, Tamil Nadu State. They identified that the QWL dimensions are adequate and fair compensation, safe and healthy work environment, and development of human capacities, growth and security, social integration, constitutionalism, total life.
Kannagi, S. A, and Mahalingam, S. (2013) in They observed the quality of work life among nonmanagerial employees in Neyveli Lignite Corporation, Neyveli, TamilNadu. They selected 792 non-managerial employees in order to determine the significance of ten categories of QWL perceptions. They are; i) pay and compensation, ii) training development, iii) recognition, iv)career development, v)job security, vi) job content, vii) safety measures viii) work schedule, ix) interpersonal relations, and $\mathrm{x}$ ) work environment. Finally they revealed that QWL has assumed significance as it is the right choice for the management to keep the employees in high sprit, and clearly be demarcated to indicate the ones in which the employees can exercise autonomy, which would go a long way in helping the organization in realizing its goals of course, with the assistance of the labour.

Rathamani, $P$. and RameshwariRamchandra. (2013)

They focused on the factors influences quality of work life of employees, level of satisfaction of employees on present; levels of QWL and influence of QWL in textile units in SIPCOT, Perundurai, in Tamil Nadu. Five respondents are selected for 10 textile units of equal capacity have been selected as sample respondent by using convenient sampling technique. In the study respondents have given favorable response on the job satisfaction, safety and healthy working conditions, opportunities to develop human capacities and opportunities for continued growth and security of their organization, and employee respondents have expected higher compensation from their employees. Research findings revealed the fact that motivational insight viz., promotion, insurance protection, training, awards, recognitions have been influencing factors of quality of work life.

\section{DATA ANALYSIS AND INTERPRETATION:}

\section{CHI-SQUARE TEST: Gender and Welfare Facilities}

\begin{tabular}{|l|l|l|l|l|l|l|}
\hline $\begin{array}{l}\text { EDUCATIONAL } \\
\text { LEVEL }\end{array}$ & $\begin{array}{l}\text { STRONGLY } \\
\text { AGREE }\end{array}$ & AGREE & NETURAL & DISAGREE & $\begin{array}{l}\text { STRONGLY } \\
\text { DISAGREE }\end{array}$ & TOTAL \\
\hline UG & 11 & 10 & 9 & 5 & 4 & 39 \\
\hline PG & 5 & 5 & 10 & 4 & 13 & 37 \\
\hline OTHERS & 7 & 5 & 2 & 7 & 3 & 24 \\
\hline TOTAL & 23 & 20 & 21 & 16 & 20 & 100 \\
\hline
\end{tabular}


H0 - There is no significant Association between Gender and Welfare Facilities.

H1 - There is a significant Association between Gender and Welfare Facilities

\begin{tabular}{|l|l|l|l|l|l|}
\hline $\begin{array}{l}\text { STATISTICAL } \\
\text { TEST }\end{array}$ & $\begin{array}{l}\text { CALCULATED } \\
\text { VALUE }\end{array}$ & $\begin{array}{l}\text { DEGREES } \\
\text { OF } \\
\text { FREEDOM }\end{array}$ & $\begin{array}{l}\text { TABLE } \\
\text { VALUE }\end{array}$ & $\begin{array}{l}\text { LEVEL SIGNIFICANCE } \\
\text { SAYPOTHESIS }\end{array}$ & HYPOA \\
\hline $\begin{array}{l}\text { Pearson Chi- } \\
\text { Square }\end{array}$ & 10.87 & 4 & 9.49 & $5 \%$ & Rejected \\
\hline
\end{tabular}

INFERENCE: It is inferred from the above that the calculated value of chi square is greater than the table value. Hence the null hypothesis is rejected so there is a significant association between Gender and Welfare Facilities.

\section{CONCLUSION:}

In order to study employees sustain in current world the perception of QWL industry is very important immense information regarding factors of quality of life ,attitude of employees towards their work life coworkers and management. This study leads me to the conclusion of every employee of the organization perceive his work life, family life to improve overall quality of life, the researcher got a very informative interaction between the employees of the exports industry to regarding QWL the researcher gave some suggestions to improve their work of life balance. In this analysis the researcher give more suggestions to improve the welfare facilities and environment condition to retain employee.

\section{REFERENCES:}

1) Akroyd D, Adams RD. The cost of caring: A national study of burnout in radiation therapists. Radiation Therapist. 2000;9:123-130.

2) Barroso J, Sandelowski M. In the field with the Beck Depression Inventory.Qualitative Health Research. 2001;11:491-504.[PubMed]

3) Beatty P, Hicks WD, Schmeidler E, Kirchner C. Investigating question meaning and context through in-depth interviews.Quality \& Quantity. 2004;38:367-379.

4) Becker HS. Outsiders: Studies in the Sociology of Deviance. London: Free Press of Glencoe; 1963.

5) Brown LD. Organizing participatory research: Interfaces for joint inquiry and organizational change. Journal of Occupational Behaviour. 1983;4:9-19. 